\title{
4 Ideologies and informality in urban infrastructure
}

\author{
The case of housing in Soviet \\ and post-Soviet Baku
}

\section{Sascha Roth}

\section{Introduction}

Since the early 2000s, the Azerbaijani state has made enormous efforts to turn its capital Baku into a showcase of modernization in urban infrastructure, housing and architecture. The authoritarian government of the oil-rich country has forged large infrastructural projects, such as renovating the old city, the seaside boulevard, parks and metro stations, as well as constructing luxurious hotels and elite housing estates in the context of Baku hosting international mega events like the 'Eurovision Song Contest' (2012), the 'European Olympic Games' (2015) or the 'Formula One Grand Prix of Europe' (2016). Preparations for these events were accompanied by largescale demolition of pre-Soviet neighbourhoods, which is often legitimized by their deficient infrastructure. Many such neighbourhoods were replaced by new infrastructural model sites such as the Flame Towers ${ }^{1}$ or park areas in the central districts. In this context, infrastructure constitutes a key concept in public discourse as being emphasized by Azerbaijan's President Ilham Aliyev:

Over the recent years, Azerbaijan has managed to assert itself globally as a dynamic, modern and strong country. [...] The city infrastructure is being modernized. Baku is one of the most beautiful cities in the world today. It is noted for its beauty, historical appearance and modernity. Additional measures will be taken to develop the urban infrastructure. We will continue to develop Baku to make it even more beautiful.

(President of the Republic of Azerbaijan - Ilham Aliyev, 2013)

Such glorifying promotion of a simultaneously past- and future-oriented nation is primarily addressed to its own citizens. The local government is applying a policy of concealment of the increasing socio-spatial inequality of urban development and those spaces that do not match with the state's envisaged promotion of the nation. These tensions constitute the wider framework for this chapter, which highlights some contrasts between the official representations of infrastructural development and the daily struggles of those citizens who live backstage of the public scenery. 
Generally, I approach infrastructure as a fluid and dynamic concept characterized by its 'ubiquity in public and scholarly discourse' (Carse, 2017, p. 34). However, the (post)socialist urban infrastructure in Azerbaijan, its official conceptualization and shifting notions in the everyday lives of citizens have remained scarcely represented in research. One of my aims, therefore, is to contribute to the comparative knowledge 'about how people produce, live with, contest, and are subjugated to or facilitated by infrastructure' (Graham and McFarlane, 2015, p. 2).

My material draws predominantly on neighbourhoods in Baku's Yasamal district (October district in Soviet times), which still contains a relatively high amount of "traditional" low-storey courtyard houses (Azerbaijani, hayat evlari) built in pre-socialist times and having been mostly inhabited by ethnic Azeris (Figure 4.1). In official discourse, such neighbourhoods have always constituted a material and social contrast to the once-Soviet 'cosmopolitan city' (Grant, 2010). My focus on the Yasamal district is of special interest because of its central location, its high number of presocialist neighbourhoods that occupy a significant amount of valuable urban space for potential new constructions, and for its ranking among the most densely populated districts in Baku. Most importantly, historical and archival documents, as well as personal accounts of local inhabitants on the Soviet ${ }^{2}$ past, point to peculiar levels of informality in the domain of housing applied by citizens and local state representatives (e.g. registration practices, the manipulation of waiting lists, illegal construction of dwellings, rooms, or the diversion of construction materials). In the following, I aim to relate the official politics of infrastructural representation in Baku with those infrastructural dynamics in 'the urban backstage' (Amin, 2014, p. 139). My ethnographic data are based on qualitative methods. I applied participant observation, which meant spending as much time as possible with informants, neighbours, friends and acquaintances from various socio-economic backgrounds in order to learn about their biographies, everyday life, challenges and perceptions of present and past urban developments. I conducted 87 structured and semi-structured interviews with architects, lawyers, non-governmental organization workers, real estate agents, scholars, shopkeepers, current and former state representatives, as well as with residents from the neighbourhoods under focus. Archival documents from the Baku branch of the 'State Archive of the Azerbaijan Republic' (SAARBB) on characteristics of Soviet housing, allocation practices, obstacles, informalities, complaint letters and newspaper articles provided historical sources on housing administrations, bureaucracies and the relations between citizens and state representatives.

All too often it seems that housing and (housing) infrastructure mark two complementary aspects, with the latter term referring to the supply of the former with electricity, water, gas, heating, etc. Instead, I advocate a more inclusive notion, which approaches housing as infrastructure being embedded in distinct social, political and historical contexts. For instance, the recent housing crisis in the USA triggered public debates on the necessity 


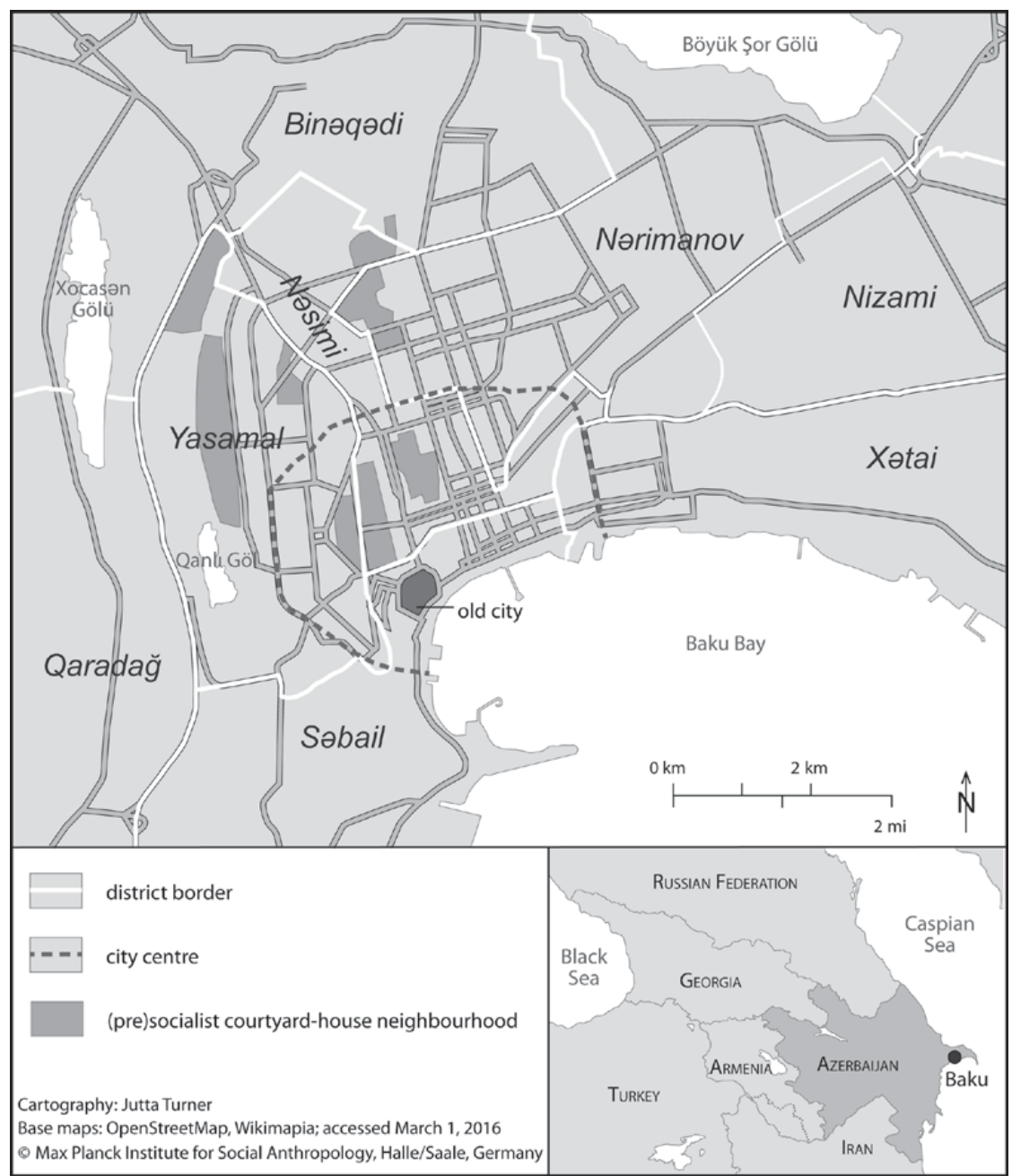

Figure 4.1 Map of Baku depicting the location of neighbourhoods in Yasamal and adjacent districts, consisting predominantly of one- and two-storey courtyard houses which have been constructed before and during the socialist era. Most buildings were being built and extended informally by the dwellers on private initiatives

Source: Map by Jutta Turner using openstreetmap.org

of classifying (affordable) housing as infrastructure. In order to increase public and private investment for housing and coming to grips with existing housing shortage, it 'should rank among America's priorities around improved roads, bridges, tunnels, railways, shipping channels, pipelines, power grids, and airports' (McManus, 2016; see also Kushner, 2010). In 
post-socialist contexts, however, where the provision of urban housing alongside other public and social infrastructures has previously been under the responsibility of a socialist state, one must apply an integrated approach to housing as infrastructure. And although most services of the socialist welfare system have disappeared in the context of neoliberalism, the experiences and nostalgic memories of the past still provide a template for many citizens for perceiving and evaluating present livelihoods and state-citizen relations on the basis of available infrastructure - predominantly housing.

While housing in the Soviet context constituted a legal right for citizens, ${ }^{3}$ its socio-cultural importance has received little attention thus far. Housing constitutes an 'intimate infrastructure', if not the most intimate one, because it provides the material, social and symbolic base for family life, marriage, social reproduction and home-making. In Azerbaijan, as in other Caucasian and Central Asian societies with a patrilineal bias, the ownership of a house or an apartment for young males is normatively regarded as a prerequisite for marriage and founding a family (although in practice young married couples often continue living with parents until they can afford a separate home). In rural Azerbaijan, it has always been the bridegroom's and his family's duty to provide housing and the necessary infrastructure after marriage. This bias hardly weakened during socialism, when it was not ownership but gaining permanent and inheritable usage rights of urban dwellings. Such moral relevance of the housing question in the domain of family life and kin support is expressed by the efforts of families and kin groups to increase the resource of housing (Roth, 2016). With regard to the peculiarities of the Soviet housing regime, it must be noted that, although having been a legal right for Soviet citizens, in practice, housing within the socialist system of 'bureaucratic allocation' (Verdery, 1991) was always perceived and represented as being a scarce resource. As such, it constituted a collective resource of kin groups that was being hoarded for the long term (Morton, 1980, p. 242). ${ }^{4}$ Informal practices and the relevance of social networks were key components in the socialist 'economy of favours' (Ledeneva, 1998). In the case of Azerbaijan, many recent works well describe the prevalence, local characteristics and embeddedness of informality in the social, economic, political and everyday life of citizens (Aliyev, 2017; Safiyev, 2015; Sayfutdinova, 2015). But especially in the little discussed sphere of housing, informal practices by citizens and bureaucrats alike have played a major role in shaping both the Soviet and post-Soviet housing regime.

The case of Baku will point to wider dynamics in other former Soviet republics regarding the material and immaterial legacies of the socialist infrastructure regime, and how they accompany and relate to current 'neoliberal' developments. Hence, I follow authors who emphasize the legacies of Soviet politics, ideologies and practices on contemporary urban transformations in post-Soviet contexts, while those very same states simultaneously seek to distance themselves from their socialist past (Grant, 2014). I shall exemplify how subtle continuities of socialist politics and people's 
past experiences with infrastructure still have a significant impact on people's everyday lives. I further argue that, despite the resilience of Soviet approaches towards infrastructure as a representation of progress and modernization, it is the very meaning and content of progress and modernity themselves that have changed, mostly through abandoning the aspects of social welfare: whereas in the Soviet narrative the socialist utopia promised a future without shortages in housing but rather with benefits for its citizens, today's emphasis in public discourse lies in the beauty, prosperity and luxury of Baku as the 'pearl of the Caspian'. Especially after the end of socialism, housing and other infrastructures transformed from a former legal right of Soviet citizens provided by the state into one of the most important venues for accelerated social exclusion and spatial inequalities. This argument resembles what the geographers Stephen Graham and Simon Marvin have called 'splintering urbanism', with which they argue that 'a parallel set of processes are under way within which infrastructure networks are being "unbundled" in ways that help sustain the fragmentation of the social and material fabric of cities' (Graham and Marvin, 2001, p. 33). According to the authors, formerly 'bundled' and integrated notions of infrastructure as connecting and unifying urban places and inhabitants become 'unbundled' and segmented, thus contributing to the process of 'splintering urbanism'. However, while the authors did not include housing in their notion of infrastructure, I suggest that, especially in post-socialist contexts, one must conceptualize housing as infrastructure because long-term legal access to cities and urban infrastructures in Soviet times was granted on the basis of a residence permit and, thus, housing. Such past experiences still matter a great deal in people's perception of and interaction with the state.

\section{Infrastructural ideologies: Soviet legacies in the present context}

The meaning of infrastructure goes far beyond its technical functioning because it conveys powerful images of civilizational progress. Speaking about the 'politics and poetics of infrastructure', anthropologist Brian Larkin argues for an analysis of infrastructures 'as concrete semiotic and aesthetic vehicles oriented to addressees. They emerge out of and store within them forms of desire and fantasy and can take on fetish-like aspects that sometimes can be wholly autonomous from their technical function' (Larkin, 2013, p. 329). Post-war notions of infrastructure became crucial tools for 'world-making' because the term gained new meanings through global processes of supra-national military coordination and economic development (Carse, 2017, p. 31). Such notions of infrastructure became especially salient in the context of the Cold War during which, both in the East and West, infrastructure became the arena of world-system competition.

Despite the conventional definition of what infrastructure is, the Bol'shaia Sovetskaia Entsiklopediia (BSE; 1969-1978) devoted most space to an ideological critique of the political economy of infrastructure in the capitalist 
West, where 'infrastructure became the object of inter-imperialist competition' and private capital owns enterprises and generates surplus value while the state is entrusted with the financing and developing of infrastructure that in turn increases the profit of the former. Such relations are taken as evidence of 'the aggressive nature of imperialism'. Whereas social problems with infrastructure are said to characterize merely the capitalist mode of production, under socialism the only remnants are technical and economic challenges being solved by scientific planning. The entry closes with an optimistic stance towards the Ninth Five-Year Plan, which envisaged accelerated development of infrastructure 'in order to meet the needs of the national economy and to increase the welfare of the working people'.

Hence, infrastructure also constituted an important internal narrative as being the material base for the forging of Soviet society and economy. Here, it was especially architecture, which, in the Soviet imagination, became the key arena of ideology (Humphrey, 2005; see also Buchli, 2007). Although such relations between infrastructure, architecture and ideology are far from being restricted to the Soviet Union, 'the Soviet example requires us to think about $[\ldots]$ the particular situation where there is a definite pronounced intention of the state to make use of the materiality of dwelling to produce new social forms and moral values' (Humphrey, 2005, pp. 39-40). Beyond the materiality of dwelling, it was also infrastructural architecture at large that contributed to crafting the image of Soviet civilization and a socialist utopia, for example through factories and industrial cities, metro stations, educational institutions, ministries or television towers (see also Collier, 2011; Kotkin, 1995; Lebow, 2013; Lodder, 2013). However, while the efficiency of material output in Soviet factories was limited, a similar or even more important characteristic in social and political terms was the 'overproduction of symbolic meanings' (Todorov, 1995, p. 10; see also Larkin, 2013, p. 335). The current processes of Baku's urban transformation and its above illustrated role as material evidence of national progress push us to be more aware of the impact of Soviet techniques and rhetoric on present infrastructural dynamics across the former Soviet Union. Allow me to exemplify some specific continuities of Soviet-style approaches towards infrastructural representation of urban development from my fieldwork: in today's Baku, fences around construction sites and public banners depict digitally embellished, futurist renderings of areas under (re)construction. Such examples of 'paper architecture' (Grant, 2014) are characteristic of Baku in the present day, but were already excessively used by the Soviet state to craft people's imaginations of the future. The term refers to 'chronicles of the built and unbuilt that circulate in ways separate from actually existing structures' (ibid., p. 507). It visualizes an idealized future that constantly lags behind its own promises. In 1972, the newspaper Baku printed a picture of the hotel 'New Inturist' (later Hotel Azerbaijan) under construction. The caption advertised the project as follows: 'No, not only in the mikroraions, not only there, where new housing estates arise, are high-rises 
growing. But also in the very centre of our city. By changing the appearance of our streets, they give them a modern face' (Baku, 1972, p. 3). Another newspaper article from 1986 praises Baku's new master development plan until the year 2005. Entitled 'A look into the future', it shows drawings and miniatures of planned model sites, high-rises and residential estates. The visual impressions are complemented by phrases such as 'a maximum of comfort for Bakuvians', or 'fast, convenient and comfortable transportation'. Furthermore, the whole city infrastructure is claimed to be further developed with 'water, heating, light, canalization', and, owing to '243,000 convenient apartments' being built, by the year 2000 every family will finally have obtained its own separate apartment (Baku, 1986). Here, paper architecture of planned developments acts as a mediator for what others have called 'the enchantments of infrastructure' (Harvey and Knox, 2012) namely the capacity of infrastructure to generate 'powerful affects of social promise' (ibid., p. 525).

Hence, housing in the Soviet context constituted an essential part of the 'infrastructural whole'. Its public representation was actively promoted by constant references to future developments and utopian visions of society embedded in socialist ideology. The Soviet techniques of promoting modernity by applying infrastructural ideologies still have a great impact on contemporary politics of representation, thus marking a continuity that is important for understanding present urban dynamics in the region. Apart from such Soviet legacy in form, we can observe changes in the content of ideology and public meaning of 'modernity' and the future. As became clear in the BSE entry, socialist approaches to infrastructure were promoted as being fundamentally distinct from capitalist ones, mainly by the absence of public goods serving the interests of private enterprise, as well as by setting emphasis on its social motivation to provide equal access to infrastructure for urban inhabitants. Today, on the contrary, infrastructural developments are attached to local images of modernity that aim to construct a closeness to Western countries by a simultaneous distancing from the Soviet past. This marks a shift from inclusive to exclusive notions of infrastructure, contributing to further socio-economic fragmentation and splintering of the urban fabric.

However, tensions between ideologically promoted official narratives and the everyday challenges experienced by many citizens were, to shifting degrees, also characteristic of the socialist period. Such ambiguities found expression in a widespread set of informal practices by families and kin groups in the housing sector, which will be discussed in the next section.

\section{Experiencing infrastructure: housing, unequal infrastructure and informality}

In different urban regions, most dwellers inhabit differing types of housing that are evaluated and hierarchized according to their quality, sanitary infrastructure and access to infrastructural facilities. Housing to a large degree 
expressed one's socio-economic standing in Soviet society because it became strongly linked to certain occupational groups, organizations and enterprises, and represented their unequal access to urban infrastructure (Andrusz, 1984; Szelényi, 1983). This observation has led some sociologists to apply the concept of 'housing classes' to the analysis and description of socialist housing systems in order to highlight the link between housing types and social stratification (Hegedüs and Tosics, 1983). However, this static model suggests fixed social boundaries between professions without sufficiently considering hierarchical differences within them. More important for the present argument is that the concept neglects the more dynamic aspects of cooperation and social support for housing, especially the practice of hoarding by which extended families (whose individual members could be of different class background and occupation), to varying degrees, established kin or house networks extending across the city. Successful hoarding practices among kin groups, predominantly among brothers and their families, allowed for flexible use of living space by means of mutual support. Moral expectations towards kin support with housing have continued after socialism (also leading to internal family conflicts if expectations are not met). The following example from the 1980s and 1990s is exemplary for similar mechanisms in Soviet times: Tofiq, his elder brother and parents were living in a two-room Khrushchevka apartment in Baku's fourth mikroraion during the 1980s. In 1994, Tofiq's father, by then employed in a higher state position and later a professor of economy, was allocated an apartment in the city centre in a residential building constructed by the government for high state officials. There the family lived together with Tofiq's uncle (Azerbaijani, ami, i.e. father's brother) who, because the family was originally from the countryside, was in need of accommodation in the capital. In the early 2000s, Tofiq's uncle became a successful businessman, earning good money and employing many relatives from his extended family. He bought a plot of land in a prestigious Baku neighbourhood and built a three-storey house, which he committed to Tofiq's father and his family. After the wedding of Tofiq's elder brother in 2014, he and his wife moved into the downtown apartment where he had once lived together with the uncle. This example suggests linking the static concept of housing classes with the more dynamic notion of housing mobility. Compared with Soviet times, when the kind of officially allocated housing was primarily connected to professional status and workplace, this link between housing quality and occupational groups has weakened. But what has not weakened are people's classifications of housing types and their different quality.

Regarding housing inequalities in the early Soviet period, scholars have pointed towards the ranking of urban dwellings 'from the unheated wooden shack, through the barracks, the hostel, the shared flat in an old house, to the separate flat in an apartment block' (Humphrey, 2005, p. 45). And still today, a further elaborate hierarchization of housing types among my interlocutors continues to shape the symbolic but also material value of different dwellings, 
because both dimensions are reflected in Baku's contemporary housing market and the monetary value of different apartment types. ${ }^{5}$

Today's heritage of Soviet mass housing consists of a variety of types colloquially known as Stalinka, Khrushchevka, Leningradskii-, Minskii-, Kievskii proekt and others. ${ }^{6}$ For instance, the solid stone walls, high ceilings, convenient layout and usually central location in contemporary Baku similarly contribute to the high standing of the Stalinkas, as does the fact that such apartments were typically allocated to the political and intellectual elite of Soviet society. Khrushchevkas, in contrast, occupy the negative extreme in the housing hierarchy - an association that was quite different during the Khrushchev era itself, when such new housing projects provided many families with a separate apartment for the first time in their family history. Today, they are associated with low ceilings, small kitchens, small bathrooms, an inconvenient passage room and thin walls, all of which could be rapidly assembled from industrially produced panels of concrete.

In addition to their types, the contemporary market value of houses has also become dependent on the condition and quality of renovation (remont), which are advertised by a whole set of terms indicating a clear hierarchy in comfort and infrastructural quality, ranging from pod maiak (only carcass/ shell structure), khoroshii remont and superremont to otlichnyi remont and evroremont. ${ }^{7}$ If the apartment is located in a novostroika (new building), sometimes it says kupcha var! - meaning 'with ownership documents' and hence indicating that the object is registered and has obtained proper documentation. This is an important fact because many new high-rises lack such documentation for several reasons (see below). Finally, I want to emphasize that the older, badly maintained courtyard houses like those in the Yasamal district enjoy the poorest reputation among Baku's population because of their dilapidated physical condition, the small size of the dwellings and their chaotic appearance (Figure 4.2). ${ }^{8}$

Hence, such neighbourhoods provide plenty of evidence for kin groups' informal strategies to obtain a separate apartment or otherwise to increase their housing resources. In Soviet times, the Yasamal district was characterized by a high level of housing-related informal practices by citizens and municipal representatives alike, with the latter sometimes being inhabitants and part of the neighbourhood community themselves. Irregularities included the formation of waiting lists and the allocation of housing, false registrations, squatting, informal construction or preferential treatment by kin members employed in the local state's housing administration (Ivanov and Sukhov, 1971). Further challenges to the district's housing system were linked to the relatively high level of privately owned dwellings in poor condition, which often lacked state support for maintenance and thus encouraged practices of informally obtaining construction materials or jumping the waiting lists for a separate apartment.

An internal enquiry by the Executive Power into the district's infrastructural challenges from 1977 stated that there were more than 3,000 privately 


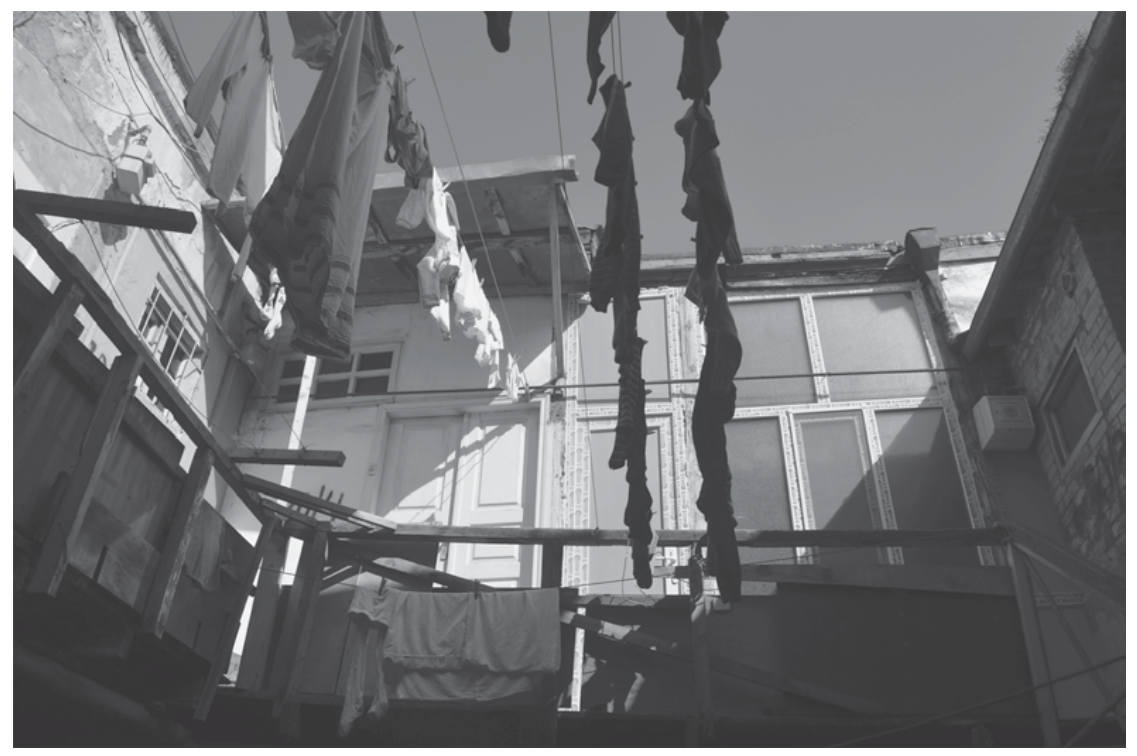

Figure 4.2 First floor in a small courtyard in the Yasamal district with several partitioned rooms. The dwelling has been continuously extended and transformed and is inhabited by members of one extended family

Source: Sascha Roth

owned single- and two-storey houses from 'pre-revolutionary' ${ }^{9}$ times with deficient infrastructure, which housed 89,444 inhabitants (SAARBB, 1977). This accounted for about 30 inhabitants per house and points to the distorted character of official statistics compared with actual living conditions. Because several rooms and dwellings within the yard were predominantly inhabited by patrilineal extended families, this necessarily contributed to higher numbers. A further reason, though, was the widespread strategy of registering relatives who, de facto, were not living in the household (see also Morton, 1980, p. 242). Such phantom registrations were made in order to gain the residence permit (propiska), which was necessary for obtaining access to the district's housing lists, social infrastructure and other services (for details on the Soviet propiska regime, see also Höjdestrand, 2009, pp. 20-45; Matthews, 1993; Morton, 1980, pp. 237-239). Soviet citizens frequently made informal registrations that were facilitated by the 'grey area' of Soviet housing law. The following quote by a former university professor exemplifies this general practice applied by many citizens across the Soviet Union:

After the birth of my two daughters, five people were registered in our dwelling. When my elder daughter married and moved to her husband's, 
I did not sign her off in order to increase my chances for receiving a bigger apartment. At the raiispolkom ${ }^{10}$ I explained that in our family we are five people and that the current three-room apartment is too small. I applied for a bigger one - that's how we got it. This was common practice everywhere; Russian families acted like this as did the Azerbaijanis everyone did it.

(Interview on 11 December 2013)

In the Yasamal district, the inflationary use of citizens' informal propiska was well-known and often tolerated among housing officials. In one case, a family of 19 people (main tenant, father, mother, two brothers, a sister, two daughters-in-law, ten nephews and a son-in-law) were officially living in a single room of 10 square metres (SAARBB, 1978). In practice, though, it was apparent that these were phantom numbers. Another issue was illegal construction and acquisition of construction materials usually because of changes in household size. As one inhabitant explains:

When it was time for one of your sons to marry, you simply built another room within the courtyard where he could live with his wife. This continued in the next generation. And when there was no more space to add supplementary rooms this way, people just continued building a second floor on top. It happened only occasionally that there were problems with the housing authorities. Most issues could be solved with bribes to make authorities turn a blind eye to it.

(Interview on 28 August 2014)

In January 1971, the Bakgorispolkom started an initiative on the 'prevention of unauthorized construction [...] of living rooms, kitchens, shower rooms, garages, etc.' - activities that 'intensify with every year' and because of which the district Soviets were instructed to investigate the issue. In 1973 alone, the local administration demolished 80 unauthorized houses, 39 garages and 80 glazed balconies. Furthermore, ten drivers who were illegally transporting construction material were arrested, and so on (SAARBB, 1976).

In today's Baku, we encounter similar obstacles in terms of proper documentation, informality and infrastructural provision (Valiyev, 2013). For instance, despite their illegal status, most informal dwellings in the city's suburban settlements are well connected to transport, water or electricity. State and private companies rarely check the legal status of properties carefully, instead delivering the requested infrastructure, usually involving bribes. Things are further complicated because 'In many cases, construction has some document issued by municipalities for a fee (very often bribes). However, subsequent elected municipality members very often do not recognize these documents as legal' (Valiyev, 2014, p. S49). As a lawyer dealing with property issues explained to me, there are even cases in which ownership documents have become subject to fraud by organized circles 
of criminal businessmen, often real estate agents with close ties to district authorities. The lawyer described one case where an owner of an empty land plot in the urban periphery living abroad discovered a house being built and inhabited on that very plot. The buyer and alternative owner had himself 'legally' obtained the land from a real estate agency with all 'proper' documentation, a fact that created a complicated legal conflict about the property in question.

Other examples of informality in housing concern the ownership of apartments in newly built mass housing estates. Here, informal practices are often linked to the apartments' connection to gas infrastructure and how it relates to the legal status of the property: only after a building's gasification can ownership documents be applied for. For many citizens, it is desirable to buy an apartment without kupcha (see earlier), usually classified as pod maiak - consisting only of the building's carcass and mains connections for water, gas and electricity - because they can save up to one third of the normal purchasing price. On the other hand, this involves a high level of risk because the completion of the building is often a matter of uncertainty. Buyers, who often have purchased the apartment before finalization of the construction process, will then carry out all the necessary work on the interior at their own risk. Many people then live in fully furnished and equipped apartments (or rent them out to others) but provide themselves with gas from a bottle. At the same time, the building's entry, staircases and empty apartments demonstrate its unfinished character. The gasification of a novostroika is the last step in the construction process, upon which the State Agency for Control over the Safety of Construction within the Ministry of Emergency Situations determines that the construction complies with safety standards and may be inhabited. According to one of my interviewees, buildings only become gasified if at least 60 per cent of the apartments are inhabited. And getting the Ministry to approve the building's safety standards often requires the payment of bribes.

Finally, it is worth returning to the still widespread informal sphere of residential registrations. Whereas people in Soviet times usually registered more people than actually inhabiting a dwelling, for reasons illustrated earlier, today the opposite seems to be the case. Many of my interlocutors are still registered at their previous address despite inhabiting another dwelling for more than a decade now. This is partly explained by the fact that people can save taxes and other expenditures for infrastructural provision that are calculated on the basis of the number of inhabitants in a dwelling. Hence, in contrast to Soviet times, the fewer people registered today, the more benefits there are for the dwellers.

\section{Conclusion}

My aim in this chapter was to examine the tensions between state politics of representation by means of infrastructure and ideology, and some of the challenges and informal strategies that people in the urban backstage have 
been experiencing and applying in Soviet and post-Soviet Baku. Contrary to the majority of existing works on infrastructure, I advocate an approach that conceptualizes housing in post-socialist contexts as infrastructure and places it at the centre of enquiry. Additionally, from the viewpoint of citizens, I consider housing an intimate infrastructure because it shapes a variety of social processes in the private lives and moral expectations of Azerbaijani citizens.

A great deal of this chapter discussed the impact of Soviet legacies on contemporary ideologies of representation and dynamics in housing. Whereas other authors have pointed to socialist legacies in the present urban boosterism (Koch and Valiyev, 2015), administrative structures and the problem of their diffuse responsibilities (Valiyev, 2013, p. 636), historical and ethnographic data on housing strategies from the viewpoint of citizens have been scarce. I have shown that, although many of the ideological underpinnings, official promotion of modernization and infrastructural developments in current Azerbaijan follow logics of Soviet governance, their very content demonstrate a significant shift owing to a different image of modernity for the independent Azerbaijani nation. The 'paper architecture' of the past carried the meaning of modernization and infrastructure as a collective good for Bakuvians. In the paper architecture of the present, both spheres represent a modernity based on national pride, prosperity and autonomy by forging exclusive mega projects and housing estates that are increasingly disconnected from urban life as it unfolds behind the façades of privileged model sites. And we might add that, contrary to Soviet mass housing that was built for masses of people, the emphasis of 'new mass housing' being built in the city within the past decade refers to masses of buildings but not to masses of residents (which becomes evident when observing the high proportion of uninhabited residential buildings in Baku).

The second section of this chapter highlighted specific continuities in the way families engaged in the informal sector in order to improve their housing situation. On a structural level, I have critically discussed the concept of housing classes in order to describe continuities in socio-spatial inequalities, while at the same time emphasizing a more dynamic understanding of the concept by describing the practice of hoarding - kin groups' collective engagement in increasing and utilizing their collective dwelling stock. Still, it is largely the type of housing obtained in Soviet times, its location, and differences in infrastructural quality that strongly influence citizens' contemporary socio-economic standing as former housing classes are translated into dwellings' monetary value in the era of market economy. Furthermore, although being embedded in a new political and economic context, housing after privatization maintained its crucial relevance as it became "the chief source of household wealth' (Zavisca, 2012, p. 1) for the majority of urban residents. In light of the uncertain labour market and low salaries, housing constitutes the most important element of financial security for the future, and the major form of capital for new home-owners with which to profitably engage in the housing market. In contrast, most owners of badly 
maintained (pre)socialist dwellings, often being built or extended informally and thus lacking proper documentation, find themselves in a disadvantaged situation. Furthermore, because of corrupt officials and the merging of political and economic power and interest with regard to urban development, many home-owners receive far too little compensation for their properties. Finally, the everyday relevance of informality in the Soviet housing framework has remained a strong factor in shaping contemporary dynamics of housing development in Baku. But whereas mechanisms such as blat and kin support remain relevant in the present, recent developments increased the role of (monetary) corruption in the public sector (e.g. education, police, administrations). Today it is money that has become a scarce resource for many, while in Soviet times it was the scarcity of housing, among other consumer goods, that led people to apply informal practices to influence and compensate for state mechanisms of resource allocation.

In general, I have aimed to show some repercussions of the Soviet housing regime on today's processes of social and economic reconfigurations in the everyday lives of citizens. This is not to say that the informal practices or tensions between ideological representation and everyday life described in this chapter are rooted in socialism. But it is the historical experience of socialist housing at large, its ideological and infrastructural emphasis as well as the peculiarities in housing policies and administration that still have great influence in the post-socialist era. The Yasamal neighbourhoods discussed here well illustrate such continuities within the contemporary urban context. In early summer 2014, roughly one year before Baku was to host the first 'European Olympic Games', the city's Executive Power began the long-prepared demolition of one such neighbourhood called Sovetski, affecting an area of 50 ha that was home to 50,000-60,000 people (Alibayli and Mahmudbeyli, 2014). Many of the inhabitants I talked to expressed their nostalgic memory of Soviet times when dwellers were compensated with new apartments. At present, however, they have received financial compensation of roughly one third the usual square metre value in this very central area - not enough even to obtain a dwelling in the outskirts for most. Hence, most inhabitants are experiencing a process of unbundling infrastructure that characterizes the global trend of splintering urbanism, and which many Bakuvians interpret in relation to nostalgic memories of the Soviet welfare state.

\section{Acknowledgements}

This chapter is based on 1-year's fieldwork conducted in Baku in 2013-2014 for my $\mathrm{PhD}$ thesis on the dynamics between housing, the family and the state in Soviet and independent Baku (Roth, 2016). I'd like to thank the Max Planck Institute for Social Anthropology in Halle/Saale, the International Max Planck Research School on the Anthropology, Archaeology and History of Eurasia, and the Graduate School Society and Culture in Motion 
for supporting this project. Furthermore, I am grateful to the editors and authors of this volume as well as to the two anonymous reviewers for their detailed comments on earlier drafts of this chapter.

\section{Notes}

1 The Flame Towers are three skyscrapers containing exclusive apartments, a 5star hotel and office blocks. They have become the modern brand of the city, dominating the central skyline, and shall represent Azerbaijan architecturally as the historical 'Land of Fire'.

2 My use of the terms '(post)socialist' and '(post)Soviet' in this chapter require some brief explanation. Both versions refer to a geographical space, a historical era, a socio-political regime or an ideology. Although I use both forms, for the following reasons, I apply (post)Soviet more frequently. First, the Caucasus had long been a part of Tsarist Russia and later of the Soviet Union. Hence, in the present context, it is more accurate to speak of (post)Soviet. Socialism in Central Eastern Europe, for instance, was different from Soviet socialism, with the latter having been established much earlier and also emerging from a distinctively different empire. Second, the terms 'socialist' or 'socialism' summarize political ideologies, visions and imaginations of society based on Marxist principles, the practical implementations and outcomes of which brought forth different realities of socialism.

3 The preface of the Soviet Housing Codex stated that 'Soviet housing legislation is designed to promote the right of citizens to housing, effective use and protection of the housing stock'. According to Article 44 of the Soviet Constitution from 1977, 'Citizens of the USSR have the right to housing' that is 'ensured by the development and upkeep of state and socially-owned housing; by assistance for co-operative and individual house building [and] by fair distribution, under public control [...]'.

4 The anthropologist Katherine Verdery (1996, p. 21) describes the widespread practice of 'hoarding' productive resources like budgets and materials in socialist economies. Such strategies allowed firms to save resources for the next production cycle, or for use as a means of exchange for needed goods with others. Although she talks about 'hoarding' on a different level, the same logic applies to families and their housing strategies. For families, housing as a collective resource of kin groups was hoarded for the next generation.

5 Housing journals, newspaper articles and advertisements, as well as interviews with and participant observation among local real estate agents, provided an important source for understanding local preferences and ascriptions to different housing types.

6 Those terms are still widely used across the former Soviet republics and refer to certain types of residential buildings having been constructed during the period of Stalin (Stalinka) or Khrushchev (Khrushchevka). Other, mostly later, types are named after the cities in which they were first projected, such as Leningrad, Minsk or Kiev.

7 The Russian term 'maiak' literally means 'lighthouse'. Among construction workers it denotes 'plaster profiles' - that is, an accessory used for achieving an even plastering of interior walls. The types of remont that follow reflect 
increasing levels of comfort, ranging from 'good', 'super' to 'excellent' renovation. Finally, 'evroremont' suggests European materials and the finest quality standards.

8 The same term for courtyard house (bayat evi) is applied to the more spacious single or multi-family houses by rural migrants and middle-class families in the suburban peripheries as well as to the traditional rural housing architecture.

9 'Pre-revolutionary' is the expression used in the archival documents I have worked with. They refer to the time prior to 1920 when the Soviets took power over Azerbaijan.

10 The raiispolkom (raionnyi ispolnitel'nyi komitet) describes each district's executive power. Each of those is subordinated to the Bakgorispolkom (Bakinskii gorodskoi ispolnitel'nyi komitet) - the central executive power of Baku city.

\section{References}

Alibayli, V. and Mahmudbeyli, F. (2014) 'There goes the neighborhood: in construction-crazy Baku, another old district faces the wrecking ball', Transitions Online: Regional Intelligence. Available at: www.tol.org/client/article/24329azerbaijan-baku-poverty-development-sovetski.html (accessed 30 November 2014)

Aliyev, H. (2017) 'Informal institutions in Azerbaijan: exploring the intricacies of tapsh', Europe-Asia Studies, 69:4, 594-613.

Amin, A. (2014) 'Lively infrastructure', Theory, Culture \& Society, 31:7/8, 137-161.

Andrusz, G. (1984) Housing and Urban Development in the USSR, Houndmills: Macmillan.

Baku (1972) Untitled, Baku, 1 May, p. 3.

Baku (1986) Baku 2005: Vzglyad v budushchee, Baku, 28 November, pp. 2-3.

Bol'shaia Sovetskaia Entsiklopediia (1969-1978). Available at: https ://dic.academic. ru/dic.nsf/bse/90931 (accessed 5 May 2017)

Buchli, V. (2007) 'Astana: materiality and the city', in Alexander, C., Buchli, V. and Humphrey, C. (eds) Urban Life in Post-Soviet Asia, London: University College London Press, 40-69.

Carse, A. (2017) 'Keyword: infrastructure: how a humble French engineering term shaped the modern world', in Harvey, P., Bruun Jensen, C. and Morita, A. (eds) Infrastructures and Social Complexity: A Companion, London: Routledge, 27-39.

Collier, S. J. (2011) Post-Soviet Social: Neoliberalism, Social Modernity, Biopolitics, Princeton: Princeton University Press.

Graham, S. and Marvin, S. (2001) Splintering Urbanism: Networked Infrastructures, Technological Mobilities and the Urban Condition, London: Routledge.

Graham, S. and McFarlane, C. (2015) 'Introduction', in Graham, S. and McFarlane, C. (eds) Infrastructural Lives: Urban Infrastructure in Context, London: Routledge, $1-14$.

Grant, B. (2010) 'Cosmopolitan Baku', Ethnos, 75:2, 123-147.

Grant, B. (2014) 'The edifice complex: architecture and the political life of surplus in the new Baku', Public Culture, 26:3, 501-528.

Harvey, P. and Knox, H. (2012) 'The enchantments of infrastructure', Mobilities, $7: 4,521-536$. 
Hegedüs, J. and Tosics, I. (1983) 'Housing classes and housing policy: some changes in the Budapest housing market', International Journal of Urban and Regional Research, 7:4, 467-494.

Höjdestrand, T. (2009) Needed by Nobody: Homelessness and Humanness in PostSocialist Russia, Ithaca: Cornell University Press.

Humphrey, C. (2005) 'Ideology in infrastructure: architecture and Soviet imagination', Journal of the Royal Anthropological Institute, 11:1, 39-58.

Ivanov, Y. and Sukhov, M. (1971) 'Komu byt' novoselom': O praktike ucheta i raspredeleniia zhil'ia v Oktiabr'skom Raione. Bakinskii Rabochii, 23 December.

Koch, N. and Valiyev, A. (2015) 'Urban boosterism in closed contexts: spectacular urbanization and second-tier mega-events in three Caspian capitals', Eurasian Geography and Economics, 56:5, 575-598.

Kotkin, S. (1995) Magnetic Mountain: Stalinism as a Civilization, Berkeley: University of California Press.

Kushner, J. A. (2010) 'Affordable housing as infrastructure in the time of global warming', The Urban Lawyer, 42/43:4/1, 179-221.

Larkin, B. (2013) 'The politics and poetics of infrastructure', Annual Review of Anthropology, 42, 327-343.

Lebow, K. (2013) Unfinished Utopia: Nowa Huta, Stalinism, and Polish society, 1949-56, Ithaca: Cornell University Press.

Ledeneva, A. (1998) Russia's Economy of Favours: Blat, Networking, and Informal Exchange, Cambridge: Cambridge University Press.

Lodder, C. (2013) 'The ghost in the machine: the modernist architectural utopia under Stalin', in Lodder, C., Kokkori, M. and Mileeva, M. (eds) Utopian Reality: Reconstructing Culture in Revolutionary Russia and Beyond, Leiden: Brill, 161-191.

Matthews, M. (1993) The Passport Society: Controlling Movement in Russia and the USSR, Boulder: Westview Press.

McManus, J. (2016) Grid Block: Why isn't Housing 'Infrastructure?'. Available at: www.builderonline.com/builder-100/strategy/grid-block-why-isnt-housinginfrastructure_o (accessed 27 May 2017)

Morton, H. W. (1980) 'Who gets what, when and how? Housing in the Soviet Union', Soviet Studies, 32:2, 235-259.

President of the Republic of Azerbaijan - Ilham Aliyev (2013) Ilham Aliyev chaired the first meeting of the Organizing Committee of the European Olympic Games due to be held in Baku in 2015. Available at: http://en.president.az/articles/7175 (accessed 21 December 2016)

Roth, S. (2016) Making a home in Baku: dynamics of housing, family and state in Azerbaijan. Thesis (PhD): Martin Luther University Halle-Wittenberg.

Safiyev, R. (2015) 'Informality in a neopatrimonial state: Azerbaijan', in Voell, S. and Kaliszewska, I. (eds) State and Legal Practice in ihe Caucasus: Anthropological Perspectives on Law and Politics, Farnham: Ashgate, 133-148.

Sayfutdinova, L. (2015) 'Negotiating welfare with the informalizing state: formal and informal practices among engineers in post-Soviet Azerbaijan', Journal of Eurasian Studies, 6:1, 24-33.

State Archive of the Azerbaijan Republic, Baku Branch (1976) O grubykh narusheniiakh semel'nogo zakonodatel'stva $v$ gorode $i$ merakh po ikh ustraneniiu $v$ svete postanovleniia BK KP Azerbaidzhana ot 8 iiulia 1973 g (4 September 1976), fond 23, opis 1, delo 1337, 5-11. 
State Archive of the Azerbaijan Republic, Baku Branch (1977) O rabote Oktiabr'skogo ispolkoma po vypolneniiu reshenii vyshestoiashchikh partiinykh $i$ sovetskikh organov $v$ chasti sokhrannosti zhilogo fonda $i$ ustraneniia narushenii imeiushchikhsia v etom voprose (20 January 1977), fond 23, opis 1, delo 1442, 1-4.

State Archive of the Azerbaijan Republic, Baku Branch (1978) O predostavlenii zhilploshchadi grazhdanam iz osvobozhdennogo zhilogo fonda (29 November 1978), fond 23, opis 1 , delo 1681, 76-77.

Szelényi, I. (1983) Urban Inequalities under State Socialism, Oxford: Oxford University Press.

Todorov, V. (1995) Red Square, Black Square: Organon for Revolutionary Imagination, Albany: State University of New York Press.

Valiyev, A. (2013) 'Baku', Cities, 31, 625-640.

Valiyev, A. (2014) 'The post-communist growth machine: the case of Baku, Azerbaijan', Cities: Supplement 1, 41, S45-S53.

Verdery, K. (1991) 'Theorizing socialism: a prologue to the "transition"', American Ethnologist, 18:3, 419-439.

Verdery, K. (1996) What Was Socialism, and What Comes Next?, Princeton: Princeton University Press.

Zavisca, J. (2012) Housing the New Russia, Ithaca: Cornell University Press. 


\section{Post-Socialist Urban Infrastructures}

Edited by Tauri Tuvikene,

Wladimir Sgibnev and

Carola S. Neugebauer 
First published 2019

by Routledge

2 Park Square, Milton Park, Abingdon, Oxon OX14 4RN

and by Routledge

52 Vanderbilt Avenue, New York, NY 10017

Routledge is an imprint of the Taylor \& Francis Group, an informa business

(C) 2019 selection and editorial matter, Tauri Tuvikene, Wladimir Sgibnev and Carola S. Neugebauer; individual chapters, the contributors

The right of Tauri Tuvikene, Wladimir Sgibnev and Carola S. Neugebauer to be identified as the authors of the editorial material, and of the authors for their individual chapters, has been asserted in accordance with sections 77 and 78 of the Copyright, Designs and Patents Act 1988.

The Open Access version of this book, available at www.taylorfrancis.com, has been made available under a Creative Commons Attribution-Non Commercial-No Derivatives 4.0 license.

Trademark notice: Product or corporate names may be trademarks or registered trademarks, and are used only for identification and explanation without intent to infringe.

British Library Cataloguing-in-Publication Data

A catalogue record for this book is available from the British Library

Library of Congress Cataloging-in-Publication Data

Names: Tuvikene, Tauri, editor. I

Sgibnev, Wladimir, 1983- editor. I Neugebauer, Carola S., 1980- editor.

Title: Post socialist urban infrastructures / edited by Tauri Tuvikene,

Wladimir Sgibnev, Carola S. Neugebauer.

Description: Abingdon, Oxon ; New York, NY : Routledge, 2019. I

Series: Routledge research in planning and urban design I

Includes bibliographical references and index.

Identifiers: LCCN 2018044581 | ISBN 9780815392651 (hardback) |

ISBN 9781351190343 (adobe pdf reader) I ISBN 9781351190336 (epub) |

ISBN 9781351190329 (mobipocket)

Subjects: LCSH: City planning-Former communist countries. I

Municipal services-Former communist countries. I

Infrastructure (Economics)-Former communist countries.

Classification: LCC HT169.E82 P67 2019 | DDC 307.1/216091717-dc23

LC record available at https://lccn.loc.gov/2018044581

ISBN: 978-0-8153-9265-1 (hbk)

ISBN: 978-1-351-19035-0 (ebk)

Typeset in Sabon

by Newgen Publishing UK

Supported by the Leibniz Association's Open Access Monograph Publishing Fund

This publication has been printed with kind support from RWTH Aachen University

\section{RWIHAACHEN

